\title{
OORDRAG VAN EIENDOMSREG IN DIE VULGÊRE REG IN DIE WES-ROMEINSE RYK
}

\section{Inleiding}

Dit word algemeen aanvaar dat 'n abstrakte stelsel van eiendomsoordrag in die Suid-Afrikaanse reg toegepas word. Kenmerkend van ' $\mathrm{n}$ abstrakte stelsel is dat die verskillende regshandelinge wat by die oordragsproses betrokke is, naamlik die verbintenisskeppende ooreenkoms, lewering of registrasie, en die saaklike ooreenkoms van mekaar geabstraheer is ${ }^{1}$ en dat elkeen sy eie vereistes het. Alhoewel algemeen aanvaar word dat die saaklike ooreenkoms sy ontstaan aan Savigny te danke het, kom die vraag by mens op of sy teorie op die Romeinse reg gegrond is. Om vas te stel of enige kenmerke van die saaklike ooreenkoms op enige stadium in die geskiedenis van die Romeinse reg aangetref kan word, is natuurlik 'n omvattende ondersoek. Dit behels onder andere, dat ondersoek ingestel moet word na die verhouding tussen die verskillende elemente in die oordragsproses in elkeen van die tydperke van die Romeinse regsgeskiedenis. ${ }^{2}$ Hierdie artikel is daarop gerig om vas te stel of daar in die vulgêre reg $^{3}$ tussen die verskillende regshandelinge onderskei is, en wat die onderskeid behels het. ${ }^{4}$

Die eerste gedeelte van die na-klassieke periode, en veral sedert Konstantyn die Grote (306-337) keiser geword het, ${ }^{5}$ word daardeur gekenmerk dat die tegniese verfynings van die klassieke reg verval en verlore geraak het, en dat die begripsvorming vaag en verwarrend was. ${ }^{6}$ Die juriste was nie meer in staat of bereid om die hoë standaarde van die klassieke reg na te streef nie, ${ }^{7}$ met die

1 Air-Kell h/a Merkel Motors v Bodenstein 19803 SA 917 (A).

2 In hierdie artikel word gesteun op Feenstra Romeinsrechtelijke Grondslagen 3 ev se periodisering van die Romeinse reg $\mathrm{nl}$ : die oud-Romeinse reg (tot 250vC), voor-klassieke Romeinse reg (250vC-27vC), klassieke Romeins reg (27vC-250nC), na-klassieke Romeinse reg (250nC-1100nC). Sien verder ook Van Zyl Romeinse Privaatreg.

3 Die vulgêre reg het die klassieke reg in die tydperk tussen 350 en 550 in die Wes-Romeinse Ryk verdring. Aangesien daar in die kodifikasie van Justinianus heelwat vulgêre reg opgeneem is, is die vulgêre reg ook vir die latere ontwikkeling van die Europese privaatreg belangrik. Sien Van der Walt Houerskap 88.

4 Die ondersoek na die verhouding tussen die verskillende elemente in ander tydperke sal in verdere artikels aan die orde gestel word.

5 Die constitutiones van keiser Konstantyn was die eerste wetgewing waarin vulgêre reg opgeneem is. Van Oven Romeinsch Privaatrecht 31; Kop 'Vulgaire' Romeinse Recht 12.

6 Dit is die degenerasie van die klassieke reg, maar ook die evolusie daarvan in die provinsies. Kop 'Vulgaire' Romeinse Recht 3, 5; Feenstra Romeinsrechtelijke Grondslagen 5; Van der Walt Houerskap 89-90.

7 Daar onstaan 'n teenkanting teen die abstrakte regsfigure van die klassieke tydperk. 
gevolg dat daar ' $n$ kwaliteitsvermindering van die regstelsel plaasvind. Hierdie verwikkelinge word tipeer as die vulgarisering van die Romeinse reg. ${ }^{8}$

Volgens Van der Walt ${ }^{9}$ omvat die begrip vulgêre reg:

(a) regsreëls en konsepte van die klassieke reg in gedegenereerde vorm,

(b) regsreëls en konsepte wat vanuit die plaaslike wetgewing (en praktyk) oorgeneem is en

(c) regsreëls en konsepte wat ten dele met inheemse reg gesintetiseer is. In hierdie vorm het die vulgêre reg in beide die Oos- en Wes-Romeinse ryke ${ }^{10}$ voorgekom, hoewel daar verskille tussen die twee gebiede was.

Levy ${ }^{11}$ verduidelik die ontwikkeling van die vulgêre reg soos volg:

The evolution of the vulgar law was essentially a process from within that had slowly and gradually developed through the centuries and had come into the open in the fourth century when, no longer hampered by the orthodoxy of the imperial chancellery, the laywers felt free to follow their own way of thinking. That way, however, necessarily deviated sharply from what it had been a hundred years earlier. Gone was the thorough training and mental force which alone would have enabled them to uphold the standards of the great jurists, to penetrate the checks and balances of their system and to adapt it organically to the needs of the time. They did not comprehend that highly artistic approach, in which any notion had its exact significance and a clear cut relation to other concepts. Instinctively and not quite aware of what they were doing, they tried to render these notions in a manner that appealed to common experience.

Van die mees ingrypende veranderinge wat in die vulgêre reg ingetree het, hou verband met die begrippe waarmee saaklike beheer aangetoon is. Dit het weer 'n uitwerking gehad op die wyses waarop eiendomsreg oorgedra is. Vervolgens sal die vulgêre siening van die vorme van saaklike beheer bespreek word met die oog daarop om die invloed wat dit op die wyses waarop eiendomsreg oorgedra is aan te toon.

8 Kop 'Vulgaire' Romeinse Recht 2-3 beskryf die begrip vulgariserend soos volg: "... dat men zich desbewust afwend van het nastreven van de klassieke maatstaven."

$9 \quad$ Van der Walt Houerskap 89-90. Raadpleeg ook Kop 'Vulgaire' Romeinse Recht 23-71 ivm die betekenis en ontstaan van die begrip vulgêre reg.

10 Sedert 330 het die Romeinse ryk twee hoofsetels gehad, nl Konstantinopel in die Ooste, en Rome in die Weste. Nadat die keiser in Rome in $476 \mathrm{nC}$ ontsetel is en die Wes-Romeinse ryk verdwyn het, is die vulgêre reg in die Weste stelselmatig deur inheemse en plaaslike reg vervang. Dit is die afloopfase van die na-klassieke reg tussen 550nC en 1100nC. Raadpleeg Van der Walt Houerskap 88, 118.

11 Levy West-Roman Vulgar Law 70-71. 


\section{Die begrippe dominium en possessio}

Aangesien die redelik duidelik omskrewe eiendomsbegrip van die klassieke reg laat vaar word, en daar teruggekeer word na die onomskrewe eiendomsbegrip van die oud-Romeinse reg, vervaag die tegniese onderskeid tussen dominium en possessio in die vulgêre reg. ${ }^{12}$ Dit beteken egter nie dat dominium en possessio met mekaar gelyk gestel is nie. ${ }^{13}$ Aangesien possessio (ongestoorde fisiese beheer oor 'n saak) die uitgangspunt was, ${ }^{14}$ word dominium in terme van possessio omskryf, wat impliseer dat dominium 'n besondere soort possessio is. ${ }^{15}$ Dit het 'n nuwe indeling van possessio tot gevolg gehad, naamlik iure possidere en corpore possidere. Eiendomsreg word as iure possidere omskryf, terwyl corpore possidere verwys na alle vorme van gewone fisiese beheer sonder eiendomsreg. ${ }^{16}$ Vir die na-klassieke juris (soos vir die leek), was fisiese beheer sonder eiendomsreg moeilik om te begryp. ${ }^{17}$ Daar word gevolglik uitgegaan van die veronderstelling dat eiendomsreg (iure possidere) en fisiese beheer as 'n reël saamval, ${ }^{18}$ sodat fisiese beheer 'n vermoede van eiendomsreg skep, en eiendomsreg 'n vermoede van 'n reg op fisiese beheer. ${ }^{19}$

'n Verdere gevolg van die feit dat 'n vermenging tussen die begrippe possessio en dominium plaasgevind het, is dat eiendomsreg (iure possidere) aan animo possidere gelyk gestel is. Terwyl die begrip animo possidere in die klassieke reg verwys het na daardie gevalle waar saaklike beheer (possessio) sonder werklike fisiese beheer moontlik was, ${ }^{20}$ het dit in die vulgêre reg verwys na eiendomsreg sonder fisiese beheer, wat iets heel anders is. ${ }^{21}$ Anders as in die klassieke reg, was eiendomsreg sonder daadwerklike fisiese beheer en bloot met die animus dus in die vulgêre reg wel

12 Terme soos dominium, proprietas, possessio, en ususfructus word vryelik uitgeruil. Levy WestRoman Vulgar Law 21 ev. Sien Van der Walt Houerskap 92-93 vir die oorsake van hierdie toedrag van sake.

13 "They were approximated rather than merged". Levy West-Roman Vulgar Law 61-63.

14 Dit het verwys na alle saaklike aansprake waar fisiese beheer ter sprake gekom het (hetsy eiendomsreg, ususfructus, voortdurende huur ens). Levy West-Roman Vulgar Law 61-63.

15 Die begrippe possidere, possessio en possessor word al hoe meer aangewend as sou dit eiendomsreg omvat. Diegene wat volgens die vulgêre reg eienaars was, is as possessores in re sua beskryf, maar diegene wat vir die een of ander rede nie as domini beskou is nie, was possessores in re aliena. Sien Van der Walt Houerskap 99-100; Levy West-Roman Vulgar Law 21 ev, 61-63.

16 Van der Walt Houerskap 96-98; Levy West-Roman Vulgar Law 64.

17 Fisiese beheer word beskou as die sigbare manifestasie van 'n reg ('n persoon is eienaar omdat hy fisies in beheer van die saak is). Levy West-Roman Vulgar Law 26 ev.

18 Die veronderstelling is gegrond op die gelykstelling van eiendomsreg, iure possidere en animo possidere.

19 Van der Walt Houerskap 98-99; Levy West-Roman Vulgar Law 61-63.

$20 \mathrm{Bv}$ waar 'n wag by 'n stapel hout geplaas word sonder dat die possessor self werklike fisiese beheer uitoefen, en bloot met die animus. Lokin Vermogensrechtelijke Leerstukken 51.

21 Sien in hierdie verband Van der Walt Houerskap 90 vn 359. 
moontlik, ${ }^{22}$ met die gevolg dat eiendomsreg (iure possessio) al hoe meer as 'n reg om fisiese beheer uit te oefen, beskou word. ${ }^{23}$ Fisiese beheer sonder 'n reg op beheer (possidere corpore) was van geen belang nie. Die begrip animo et corpore possidemus verwys nou na die situasie waar die eienaar werklik fisies in beheer van die saak was. ${ }^{24}$

Verdere ontwikkelinge wat vir die onderhawige onderwerp van belang is, is die volgende:

(a) Die behoefte aan meer as een soort eiendomsreg verval, met die gevolg dat daar in die vulgêre reg net een soort eiendomsreg bestaan wat wyd genoeg is om selfs sekere vorme van possessio en beperkte saaklike regte in te sluit. ${ }^{25}$ Selfs persone met die animus rem sibi habendi ${ }^{26}$ is dikwels as domini beskryf. ${ }^{27}$

(b) Die saaklike funksie (verjaring) van possessio het bly voortbestaan, maar anders as in die klassieke reg, is 'n iusta causa en bona fides nie meer vereistes vir verjaring nie. Enige vorm van daadwerklike fisiese beheer wat deur lang tydsverloop die corpore possessor teen die eiendomsaksie sou beskerm, het na afloop van die termyn iure possessio (eiendomsreg) geword. ${ }^{28}$

(c) Die regspolitieke funksie van possessio het ook bly voortbestaan, en die interdikte het hulle bestaansreg as afsonderlike remedies teen eierigting en geweld behou. ${ }^{29}$ Omdat die regmatigheid van possessio by die interdik betrek is, het dit sy klassieke karakter, waarvolgens die regmatigheid van die beheer vir die doeleindes van die interdikte irrelevant was, verloor. ${ }^{30}$

\section{Die onderskeid tussen verbintenisskeppende ooreenkoms en oordrag van fisiese beheer}

Die konstruksie van die saaklike ooreenkoms onderskei tussen verbintenisskeppende ooreenkoms (soos koop of skenking) en die oordrag van fisiese beheer (synde die saaklike oordragshandeling) as

22 Kaser Das Römische Privatrecht II 247-248; Levy West-Roman Vulgar Law 29-31.

23 "Possidere, possessio and possessor began to be commonly applied to indicate the legal and permanent character of the control over property". Levy West-Roman Vulgar Law 21.

24 Dit behoort duidelik te wees dat daar 'n verandering ingetree het wat betref die betekenis van die begrip animus et corpore. Sien Kaser Das Römische Privatrecht II 247-248.

25 Die hantering van die verskillende eienaars se regte impliseer egter die bestaan van 'n dubbele eiendomsreg (dominium duorum in solidum), soos blyk uit die gelyktydige bestaan van twee soorte dominium ten opsigte van dieselfde stuk grond (waarvan die een uiteraard altyd sterker is as die ander). Sien hieroor Van der Walt Houerskap 108-109; Levy West-Roman Vulgar Law 67.

26 Persone wat hulleself as domini beskou het, soos die huurder en ususfructuarius.

27 Die skerp onderskeid tussen dominium en ius in re aliena het sodoende verdwyn. Levy WestRoman Vulgar Law 63.

28 Van der Walt Houerskap 100-101.

29 Die karakter van die interdikte het egter verander deurdat die herstellende funksie daarvan sterker na vore getree het. Van der Walt Houerskap 102.

30 Raadpleeg Van der Walt Houerskap 101-103. 
twee afsonderlike en selfstandige handelinge. Dit was ook die posisie in die klassieke reg, ${ }^{31}$ maar in die vulgêre reg het hierdie onderskeid verdwyn. ${ }^{32}$ Hierdie ontwikkeling hou verband met die feit dat dominium en possessio nader aan mekaar gekom het. ${ }^{33}$ Soos in die oud-Romeinse reg, word die koop weer as 'n kontantkoop of ruilkoop beskou, waar die koopsaak oorgedra word gelyktydig met betaling van die koopprys. ${ }^{34}$ Totstandkoming van, en voldoening aan die kontrak het op dieselfde tydstip plaasgevind. Indien die partye ooreengekom het dat die koopprys later betaal sou word (in geval van krediet), kon besondere reëlings by wyse van stipulatio getref word. ${ }^{35}$ Die feit dat die onderskeid tussen koop en die oordragshandeling verdwyn het, het tot gevolg gehad dat eiendomsreg oorgegaan het deur sluiting van die koopkontrak (of skenking), wat tegelykertyd ook saaklike oordragshandeling (traditio) was. $^{36}$ Traditio was die algemene wyse van oordrag, alhoewel mancipatio (in geval van res mancipi) steeds voorgekom het. ${ }^{37}$

\section{Betaling van die koopprys}

In die vulgêre reg het die opvatting dat geen eiendomsoorgang by koop moontlik was nie, tensy die koopprys betaal is, onder Hellenistiese invloed weer na vore gekom. ${ }^{38}$ Betaling van die koopprys was 'n voorvereiste vir die geldigheid van die koopkontrak. Indien die koopprys nie betaal is nie, dan was daar geen geldige koopkontrak nie, en het eiendomsreg ook nie oorgegaan nie. ${ }^{39}$ Hierdie reël word ook in wetgewing vervat. ${ }^{40}$ Indien die koper sou versuim om die koopprys te betaal, kon hy nie net verplig word om dit wel te betaal nie, hy het ook die saak verbeur, en moes dit aan die vervreemder teruggee indien hy reeds fisies in beheer gestel is. ${ }^{41}$

31 In die klassieke reg is eiendomsreg deur traditio oorgedra mits (1) die verkryger fisies in beheer van die saak gestel is en (2) oordrag van fisiese beheer op grond van 'n iusta causa geskied het.

32 Sien Kaser Das Römische Privatrecht II 275.

33 Levy West-Roman Vulgar Law 127.

34 Kaser Das Römische Privatrecht II 276; Levy West-Roman Vulgar Law 156. Hierdie reël word ook aangetref in die Codex Euricianus 286, die kodifikasie van die regsreëls in die WesGotiese ryk teen ongeveer 475 deur koning Eurik.

35 Levy West-Roman Vulgar Law 127; Kaser Das Römische Privatrecht II 276.

36 Kaser Das Römische Privatrecht II 275. Levy West-Roman Vulgar Law 127 merk op: "Sale meant conveyance or transfer". Traditio was tegelyk koopkontrak en verskaffing van fisiese beheer (oordragshandeling). Anders gestel: koop=traditio, en traditio=koop.

37 Kaser Das Römische Privatrecht II 274; Dondorp en Schrage Levering 25.

38 Daar moet egter daarop gewys word dat daar nie eenstemmigheid bestaan met betrekking tot die vraag of die prysbetalingsreël wel in die voor-Justiniaanse na-klassieke reg toegepas is nie. Sien hieroor Honsell, Mayer-Maly en Selb Römisches Recht 162-163.

39 Levy West-Roman Vulgar Law 131-133; Feenstra Romeinsrechtelijke Grondslagen 65; Kaser Das Römische Privatrecht II 278.

40 Novellae Valentiniani $32 \mathrm{pr}-3$ wat dateer uit 451nC.

41 Kaser Das Römische Privatrecht I 418; sien ook Kaser Das Römische Privatrecht II 278 vn 36. 


\section{Vormvereistes - dokumente en registrasie}

In die hedendaagse Suid-Afrikaanse reg word verbintenisskeppende ooreenkomste dikwels aan streng vormvereistes, waaronder skrif, onderwerp. Daarbenewens word vir die oordrag van eiendomsreg in onroerende goed vereis dat 'n transportakte in die akteskantoor geregistreer word. Dit laat die vraag ontstaan wat die posisie in die Romeinse reg was.

In die oud-Romeinse reg was dit nie gebruiklik om regshandelinge op skrif te stel nie omdat skrif vir die Romeine toe nog 'n vreemde verskynsel was. Dit was eers gedurende die voor-klassieke tyd dat die Romeine, onder invloed van die Grieks-Hellenistiese kultuur, van skrif gebruik gemaak het om regshandelinge te boekstaaf. ${ }^{42}$ In geval van oordrag by wyse van mancipatio is aktes reeds sedert die klassieke reg gebruik in die plek van die omslagtige formaliteite. ${ }^{43}$

Die oorgang van die klassieke na die na-klassieke tyd, word gekenmerk deur die toenemende verskrifteliking van die regsverkeer. Dit kan hoofsaaklik toegeskryf word daaraan dat daar 'n behoefte bestaan het aan bewysmiddele. Die verskaffing van fisiese beheer opsigself, het nie aan die verkryger absolute sekerheid verleen nie, aangesien die vervreemder nog altyd kon beweer dat fisiese beheer byvoorbeeld verleen is uit hoofde van locatio conductio (huur), commodatum (bruikleen) of depositum (bewaargewing). ${ }^{44}$ Ten einde die causa traditionis (die beweegrede uit hoofde waarvan die saak oorgedra is) te bewys, het dit al hoe meer gebruiklik geword om van getuies of dokumente by traditio gebruik te maak. ${ }^{45}$

Daar moet onderskei word tussen gevalle waar skrif 'n vereiste was vir die totstandkoming van die regshandeling, ${ }^{46}$ en gevalle waar skrif bloot as bewysmiddel gebruik is. ${ }^{47}$

\subsection{Skrif as geldigheidsvereiste}

In die klassieke tyd is skrif slegs in uitsonderlike gevalle as vereiste vir die geldigheid van sekere regshandelinge gestel, soos byvoorbeeld in geval van obligationes litteris contractae, ${ }^{48}$ skriftelike testamente en die formula wat in 'n regsproses gebruik is. ${ }^{49}$ In die na-klassieke tyd het die

42 Kaser Das Römische Privatrecht I 230-231; Kaser Privaatrecht 49-51.

43 Kaser Das Römische Privatrecht II 274; Dondorp en Schrage Levering 25.

44 Traditio alleen het nie aan die verkeersbehoeftes voldoen nie.

45 Levy West-Roman Law 128, 131.

46 Sonder opskrifstelling was daar geen geldige regshandeling nie.

47 Die regshandeling is geldig selfs al is dit nie op skrif gestel nie. Kaser Das Römische Privatrecht I 231.

48 Dit is verbintenisse wat tot stand gekom het deurdat die pater familias geld wat geleen is in ' $n$ kas- of huishoudboek aangeteken het. Sien Kaser Privaatrecht 200.

49 Kaser Das Römische Privatrecht I 231. 
obligationes litteris contractae en die prosesformula egter in onbruik geraak, en was skrif regtens voorgeskryf slegs in geval van testamente. ${ }^{50}$

Sedert Diocletianus (284nC-305nC) was dit onder invloed van die vulgêre reg gebruiklik om belangrike regshandelinge op skrif te stel, aangesien dokumente in 'n regsproses hoër bewyskrag geniet het as ander vorme van bewys. ${ }^{51}$ Keiser Konstantyn het in $337 \mathrm{nC}$ 'n wet gepromulgeer wat verskeie vormvereistes op die vervreemding van grond (fundus Italicus) van toepassing gemaak het. $^{52}$ Alhoewel skrif nie uitdruklik deur die wet voorgeskryf is nie, het die geldigheid van 'n regshandeling en die bewysbaarheid daarvan hand aan hand gegaan, met die gevolg dat skrif 'n vanselfsprekendheid was (dit was gebruiklik om 'n skriftelike akte op te stel). In die geval van 'n koopkontrak van grond (wat tegelykertyd traditio en oordrag van eiendomsreg was) het die wet skrif gevolglik as geldigheidsvereiste veronderstel. ${ }^{53}$ Ook ander wetgewing het in navolging van die praktyk, skrif as 'n vereiste veronderstel en dit daarom nie nodig geag om dit uitdruklik te stel nie. ${ }^{54}$ Dit is egter nie duidelik of skrif 'n konstitutiewe vereiste dan wel blote bewysmiddel was nie. Dit wil voorkom asof die geldigheid van die regshandeling en oordrag van eiendomsreg nie van skrif afhanklik was nie, en dat skrif bloot die doel gedien het om bewys te vergemaklik. ${ }^{55}$

Konstantyn se wetgewing het verder vereis dat die koper aanspreeklikheid vir die betaling van grondbelasting moet aanvaar, dat bure as getuies by die oordrag teenwoordig moes wees, en dat die verkoper in hulle teenwoordigheid moet verklaar dat hy eienaar is. Indien hierdie vereistes nie nagekom is nie, was die koopkontrak nietig. ${ }^{56}$ Daarbenewens het die Novellae Valentiniani vereis dat 'n skriftelike akte van die koop in munisipale registers geregistreer moes word. ${ }^{57}$ Hierdie vereiste is egter nie altyd in die praktyk nagekom nie, en weinig spore daarvan word in latere wetgewing

50 Mondelinge testamente is nogtans toegelaat. Kaser Das Römische Privatrecht II 75.

51 Die akte het slegs prima facie bewys verskaf van die inhoud van die regshandeling, dit kon dus weerlê word. Kaser Privaatrecht 49.

52 Fragmenta Vaticana 35.3-35.5. Diè vereistes is ook vervat in die Codex Theodosianus 3.1.2 en die Lex Romana Burgundionum. Die vereistes was hoofsaaklik daarop gerig om te verseker dat grondbelasting deur die eienaar betaal word. Sien Levy West-Roman Law 129; Kaser Das Römische Privatrecht II 277.

53 Die wetgewer het dit nie nodig geag om skrif voor te skryf nie, omdat dit vanselfsprekend was. In die geval van grond volg die skrifvereiste uit Fragmenta Vaticana 35.4 (contractus sollemniter explicatur) en 35.5 (sollemnia celebrentur). Sien Kaser Das Römische Privatrecht II 77 vn 29. Dit wil ook voorkom asof die Codex Justinianus 4.3.1.2, wat uit die tydperk van Honorius en Arcadius afkomstig is, skrif as 'n vereiste stel.

54 Skrif was bv 'n vereiste vir 'n bruidskat, huweliksluiting en egskeiding. Kaser Das Römische Privatrecht II 77.

55 Sien Dondorp en Schrage Levering 23-24; Kaser Das Römische Privatrecht II 77, 277.

56 Kaser Das Römische Privatrecht II 277; Levy West-Roman Law 129.

57 Novellae Valentiniani 15.3, 'n wet van Keiser Valentinianus III wat dateer uit 444nC. Die doel was eweneens om die invordering van belasting te vergemaklik. 
aangetref. $^{58}$ In die prakryk is koopkontrakte wat op die vervreemding van grond betrekking gehad het, nogtans op een of ander wyse amptelik deur 'n owerheidsamptenaar geregistreer. ${ }^{59}$

Ook skenkings word sedert Konstantyn aan verskeie vormvoorskrifte onderwerp wat hoofsaaklik openbaarmaking en die invordering van belasting ten doel gehad het. Die vereistes is: 'n skriftelike akte moes opgestel word, fisiese beheer moes voor getuies verskaf word (traditio), die skenking en die feit dat die saak fisies oorhandig is moes geregistreer word. Indien die vormvereistes nie nagekom is nie, was die skenking nietig. ${ }^{60}$ In geval van roerende sake van geringe waarde was dit egter nie noodsaaklik dat die skenking op skrif gestel word nie, fisiese oorhandiging was voldoende. ${ }^{61}$ Levy $^{62}$ wys daarop dat die skenking in die na-klassieke tyd drasties van die skenking in die klassieke reg verskil het. 'n Blote mondelinge skenkingsbelofte was nie geldig nie, dit moes aan die vormvereistes voldoen het. Voordat traditio plaasgevind het, het die begunstigde nog geen reg verkry nie, en kon hy die skenking nie afdwing nie. Is die ooreenkoms (belofte) op skrif gestel en word die begunstigde fisies in beheer van die saak gestel, is die skenking geldig en word hy eienaar. Die skenkingsooreenkoms was nou nie meer causa nie, want die skenking kom tot stand op die tydstip waarop die saak oorgedra word - totstandkoming en voldoening vind gelyktydig plaas. ${ }^{63}$

\section{$5.2 \quad$ Bewysaktes}

Afgesien van die regshandelinge waar skrif as vormvereiste gestel is, is dokumente aangetref wat nie 'n vereiste vir die geldigheid van die regshandeling was nie, maar wat slegs as bewysmiddel gedien het. ${ }^{64}$ Die volgende soorte skriftelike bewysaktes is veral belangrik.

(a) Die testatio was 'n plegtige akte wat in die derde persoon en in teenwoordigheid van getuies $^{65}$ opgemaak is, en wat bestaan het uit twee plankies (houttablette) wat met was bestryk is (tabulae ceratae). Afgesien van hout is papirus (charta), perkament (membrana) en ander materiaal ook gebruik, maar hout was in die klassieke tyd die suiwer Romeinse vorm. ${ }^{66}$ Verskillende soorte regshandelinge kon in so 'n akte vasgelê word, byvoorbeeld koop (met of sonder mancipatio) huur, geldlening, stipulatio,

58 Kaser Das Römische Privatrecht II 277; Levy West-Roman Law 130.

59 Levy West-Roman Law 130.

60 Fragmenta Vaticana 249.5-249.8 wat ook opgeneem is in die Codex Theodosianus 8.12.1 en die Codex Justinianus 4.3.1.2 en 8.53.25. Sien in hierdie verband Kaser Das Römische Privatrecht II 81; Dondorp en Schrage Levering 25.

61 Kaser Das Römische Privatrecht II 281; Levy West-Roman Law 137 ev.

62 Levy West-Roman Law 145-146.

63 Dws dat eiendomsreg direk deur die skenking oorgegaan het (skenking was 'n wyse van eiendomsoordrag). Sien Delport Eiendomsoordragshandelinge 120 ev.

64 Kaser Privaatrecht 50; Honsell, Mayer-Maly en Selb Römisches Recht 109.

65 Daarom word dit ook getuie-aktes genoem.

66 Van Oven Romeinsch Privaatrecht 70-71; Kaser Das Römische Privatrecht I 231-233. 
kwitansies, en ook ander juridies relevante gebeure soos geboortes, getuieverklarings, ensovoorts. ${ }^{67}$ Indien die akte op 'n koopkontrak betrekking gehad het, is die volgende inligting weergegee: die feit van kontraksluiting, ${ }^{68}$ 'n omskrywing van die koopsaak, die koopprys, die name van die partye en getuies, asook al die bykomende bedinge (leges). ${ }^{69}$ Die wastafeltjies word dan op mekaar neergesit, met die geskrif na die binnekant, en aan mekaar vasgebind met ' $n$ tou wat deur gaatjies in die rand van die tablette geryg word. Ten einde vervalsing te voorkom, word die punte van die tou verseël met die seëls van die persoon wat die akte opgestel het en die getuies - hierna word verwys as die diptychon (ook scriptura interior). ${ }^{70}$

Die probleem was egter dat daar nou nie meer gelees kon word wat die inhoud van die akte was nie, in elk geval nie voordat dit aan die regter in 'n regsproses voorgelê en oopgemaak is nie. Gevolglik is die inhoud van die akte ook op die buitekant van een van die houttablette neergeskryf sodat dit te alle tye gelees kon word (scriptura exterior), en as die inligting te veel was, is van 'n derde houttablet (triptychon) gebruik gemaak wat eweneens deur 'n stuk tou aan die ander vasgeheg is. Dit is egter nie verseël nie. Indien een van die partye die regshandeling wil bewys, is die akte as bewysstuk aan die regter voorgelê, wat die seëls kon verifieer, dit verbreek en kennis neem van die inhoud van die akte. ${ }^{71}$ In die na-klassieke tyd het die testatio verdwyn, en is dit vervang deur aktes wat deur getuies mede-onderteken is, wat in baie gevalle dwingend voorgeskryf is. ${ }^{72}$

(b) Afgesien van die testatio was daar ook die chirogram. ${ }^{73}$ Dit was 'n dokument wat eiehandig in die eerste persoon geskryf is, en wat deur ondertekening deur die outeur bewyskrag verkry het. Geen getuies was nodig nie. Uit die dokumente wat oorgelewer is, blyk dit dat die testatio en die chirogram in verskeie opsigte met mekaar vermeng geraak het. ${ }^{74}$ Mettertyd word dit gebruiklik om die chirogram deur beroepskrywers (tabelliones) te laat opstel.

(c) 'n Derde soort dokument verdien vermelding, naamlik 'n akte (chirogram) wat deur beroepskrywers (tabelliones) opgestel is (instrumenta publice confecta) en wat veral in die tyd van Justinianus 'n rol gespeel het. Die beroep van die tabelliones het sy

67 Kaser Das Römische Privatrecht I 232.

68 In geval van mancipatio word gemeld dat die mancipatio-handeling uitgevoer is.

69 Van Oven Romeinsch Privaatrecht 70-71.

70 Van Oven Romeinsch Privaatrecht 70-71; Kaser Das Römische Privatrecht I 232.

71 Van Oven Romeinsch Privaatrecht 70-71; Kaser Das Römische Privatrecht I 232.

72 Kaser Das Römische Privatrecht II 78; Honsell, Mayer-Maly en Selb Römisches Recht 110.

73 Afgelei van die Griekse woorde wat "met die hand skryf" beteken. Dit is reeds sedert die einde van die Republiek gebruik.

74 Daar is dokumente wat kenmerke van beide vertoon. Kaser Das Römische Privatrecht I 232233; Honsell, Mayer-Maly en Selb Römisches Recht 110. 
ontstaan te danke aan die feit dat amptenare wat by die staatsadministrasie betrokke was, hulle dienste (op 'n privaat grondslag) aan die publiek beskikbaar gestel het deur te help met die opstel van dokumente en die partye van raad te bedien. ${ }^{75}$ Die tabelliones het die vorm en inhoud van formuliere wat in Griekse dokumentasie (veral koopaktes) gebruik is oorgeneem. Sodoende word geykte formuliere op alledaagse regshandelinge toegepas, wat natuurlik gelykvormigheid tot gevolg gehad het. ${ }^{76}$ Justinianus het sekere vormvereistes voorgeskryf waaraan die dokumente moes voldoen: ${ }^{77}$ die dokument moes deur die partye onderteken word (subscriptio); indien 'n tabellio meegewerk het, moes hy die dokument voltooi (complere) deur sy onderskeidende merk op die dokument aan te bring en dit te onderteken; die partye moes dit goedkeur (absolvere), en die dokument moes dateer word en deur getuies onderteken word. ${ }^{78}$

Aktes wat deur tabelliones opgestel is, het in die Justiniaanse reg besondere bewyskrag geniet, soortgelyk aan aktes wat deur ten minste drie getuies onderteken is. Die tabellio moes die egtheid en die opstel daarvan onder eed bevestig. ${ }^{79}$ In die klassieke reg kon die regter self besluit watter bewyskrag hy aan die getuienis wat aan hom voorgelê is gaan heg, ${ }^{80}$ maar in die na-klassieke reg het dokumentêre getuienis egter swaarder geweeg as getuienis deur getuies of ander bewysmiddele. Dokumentêre getuienis kon slegs weerlê word indien aangetoon word dat die akte vervals is. As die egtheid egter vasstaan, kon die inhoud daarvan nie aangeval word nie. ${ }^{81}$

Die belangrikste gevolgtrekking uit bogenoemde bespreking vir die onderhawige onderwerp is dat vormvereistes ten opsigte van die oordrag van onroerende goed in die vulgêre reg ingevoer word, waaronder 'n skriftelike koopakte (hetsy as geldigheidsvereiste, hetsy as blote bewysmiddel) wat in munisipale registers geregistreer is. ${ }^{82}$ Hierdie vorm van registrasie kan egter nie aan die hedendaagse praktyk waarvolgens 'n transportakte in die akteskantoor geregistreer word, gelyk gestel word nie.

75 Justinianus het die gebruik van tabelliones in Codex 4.21.17pr verpligtend gemaak. Sien ook Kaser Das Römische Privatrecht II 78-79.

76 Kaser Das Römische Privatrecht II 52-54.

77 Sien Codex 4.21.17 (528nC).

78 Kaser Das Römische Privatrecht II 79.

79 Kaser Das Römische Privatrecht II 79-80.

80 Die partye kon besluit op die bewysmiddel wat hulle gaan gebruik aangesien alle bewysmiddele ewe bewyskragtig was.

81 Kaser Das Römische Privatrecht II 75-76.

82 In geval van skenkings was skrif en registrasie konstitutiewe vereistes. 


\section{Fisiese beheer}

Soos wat reeds aangetoon is, onderskei die konstruksie van die saaklike ooreenkoms tussen die causa en verskaffing van fisiese beheer as twee afsonderlike regshandelinge. In die Suid-Afrikaanse reg speel die verskaffing van fisiese beheer 'n belangrike rol by die oordrag van eiendomsreg. Behoudens enkele uitsonderingsgevalle kan eiendomsreg nie oorgaan nie tensy die verkryger fisies in beheer van die saak gestel word. ${ }^{83}$ Die verskaffing van fisiese beheer alleen is egter nie voldoende nie, aangesien dit gepaard moet gaan met die bedoeling om eiendomsreg oor te dra en te ontvang (die saaklike ooreenkoms). ${ }^{84}$ Daar is reeds daarop gewys dat die onderskeid tussen causa en lewering nie in die vulgêre reg bestaan het nie, aangesien kontraksluiting en verskaffing van fisiese beheer uit een enkele handeling bestaan het. Dit laat die vraag onstaan wat presies die rol was wat verskaffing van fisiese beheer in die vulgêre reg gespeel het.

Die koopprysreël en vormvereistes wat sedert die tyd van Konstantyn die lig gesien het, het 'n belangrike invloed uitgeoefen op die oordrag van eiendomsreg. Indien die vormvereistes nie nagekom is nie, of indien die koopprys nie betaal is nie, of sekerheid vir betaling nie gestel is nie, het geen geldige kontrak tot stand gekom nie, met die gevolg dat eiendomsreg ook nie oorgegaan het nie, ${ }^{85}$ selfs al is fisiese beheer reeds verskaf. ${ }^{86}$ Dit het volgens sommige bronne ${ }^{87}$ tot gevolg gehad dat verskaffing van fisiese beheer (traditio corporalis) nie meer 'n vereiste vir die oorgang van eiendomsreg was nie - eiendomsreg het op die verkryger oorgegaan selfs sonder dat fisiese beheer verskaf is, mits die koopprys betaal is en die vormvoorskrifte nagekom is. ${ }^{88}$ Aangesien die klem na die nakoming van die vormvoorskrifte en betaling van die koopprys verskuif het, het verskaffing van fisiese beheer (traditio) op die agtergrond geraak. ${ }^{89}$ Die begrip traditio het nou nie meer net na die verskaffing van fisiese beheer verwys nie, dit het ook na die ooreenkoms tussen die partye (byvoorbeeld die koopkontrak) sonder dat fisiese beheer verskaf is, verwys. ${ }^{90}$ Alhoewel fisiese

83 Dit gee uiting aan die publisiteitsbeginsel.

84 Die vraag of verskaffing van fisiese beheer en die saaklike ooreenkoms twee afsonderlike en onafhanklike handelinge is, word daargelaat. Aangesien daar in die Romeinse reg geen sprake van 'n saaklike ooreenkoms was nie, is daar ook geen sprake van enige verband tussen die verskaffing van fisiese beheer en die saaklike ooreenkoms nie.

85 Dit wil dus voorkom asof ' $n$ kousale stelsel toegepas is.

86 Levy West-Roman Law 132-133: "Where there is no payment, there is no sale or conveyance"; Kaser Das Römische Privatrecht II 280; Molkenteller Dingliche Vertrag 69.

87 Raadpleeg Kaser Das Römische Privatrecht II 280; Levy West-Roman Law 134, 137.

88 Alhoewel fisiese beheer in die tyd van Diocletianus (284nC-305nC) nog deurslaggewend was (Codex 4.19.12), is die posisie deur die wetgewing van Konstantyn verander (aldus die bronne in die vorige voetnoot).

89 Lokin Vermogensrechtelijke Leerstukken 173-174. Eiendomsreg gaan oor deur betaling van die koopprys, en nie deur verskaffing van fisiese beheer nie. Was dit nie vir die koopprysreël nie, dan sou die koper eers eienaar geword het nadat fisiese beheer verskaf is, selfs al is die koopprys nog nie betaal nie.

90 Levy West-Roman Law 136. 
beheer nie meer 'n vereiste vir oordrag van eiendomsreg was nie, is die verkryger nogtans in praktyk wel fisies in beheer van die saak gestel. ${ }^{91}$

Verskaffing van fisiese beheer was volgens die bronne waarna in die vorige paragraaf verwys is, ${ }^{92}$ slegs 'n vereiste vir oordrag van eiendomsreg wanneer roerende goed van geringe waarde verkoop is sonder dat 'n koopakte opgestel is, en wanneer grond in Italië (res mancipi) by wyse van mancipatio oorgedra is. ${ }^{93}$ In laasgenoemde geval moes die grond na mancipatio nog fisies aan die verkryger oorhandig word. Die gebeure moes op die grondstuk self plaasvind, en die eienaar van die naburige grond moes as getuie teenwoordig wees. ${ }^{94}$

Hierdie siening is vir kritiek vatbaar. ${ }^{95}$ Dit laat die feit dat verskaffing van fisiese beheer 'n onlosmaaklike deel van kontraksluiting was, buite rekening. Die grondliggende ooreenkoms (soos koopkontrak of skenking) en die saaklike oordragshandeling was nie meer van mekaar geskei nie, dit het gelyktydig plaasgevind. ${ }^{96}$ Die reël was dat eiendomsreg deur sluiting van die koopkontrak oorgegaan het - nakoming van die kontrak vind onmiddellik plaas. ${ }^{97}$ Indien fisiese beheer nie verskaf is nie, kon geen kontrak tot stand kom nie, en kon eiendomsreg ook nie oorgegaan het nie. ${ }^{98}$ Dit moet verder in gedagte gehou word dat daar nie eenstemmigheid bestaan met betrekking tot die vraag of die prysbetalingsreël wel in die voor Justiniaanse na-klassieke reg toegepas is nie. ${ }^{99}$

Dit is ook onwaarskynlik dat die gebruikmaking van dokumente fisiese beheer as vereiste vir eiendomsoordrag sou verdring. Dit word algemeen aanvaar dat dit nie moontlik was om 'n akte te oorhandig in plaas daarvan om fisiese beheer te verskaf nie - traditio per cartam het nie die plek van fisiese beheer ingeneem nie. ${ }^{100}$ Die skriftelike dokument was bloot bewysmiddel, dit was nie

91 Levy West-Roman Law 134, 137.

92 Levy West-Roman Law 134, 136-137; Kaser Das Römische Privatrecht II 280; Lokin Vermogensrechtelijke Leerstukken 173-174.

93 Kaser Das Römische Privatrecht II 280; Levy West-Roman Law 137; Dondorp en Schrage Levering 24-25.

94 Mancipatio in absentia was nie moontlik nie. Dondorp en Schrage Levering 25. Hierdie standpunt berus op die siening dat die formaliteite by mancipatio of die oorhandiging van die akte nog nie die verskaffing van fisiese beheer veronderstel het nie.

95 Sien ook Voß Kaisergesetzen der Spätantike $131 \mathrm{ev.}$

96 Die koopkontrak kom tot stand deurdat die saak oorgedra en die prys betaal word.

97 "A donation, like a sale, was no longer recognized except as a simultaneous act: unless performed, it was legally not in existence". Levy West-Roman Law 139-140.

98 Indien daar in die praktyk weer 'n skeiding tussen die verskillende elemente plaasgevind het (bv, as gevolg van die gebruikmaking van dokumente of die reëls wat op die betaling van die koopprys betrekking gehad het), behoort dit geen invloed te gehad het op die vraag of fisiese beheer in teorie 'n noodsaaklike element vir die oordrag van eiendomsreg was nie.

99 Sien hieroor Honsell, Mayer-Maly en Selb Römisches Recht 162-163.

100 Sien Levy West-Roman Law 128, 146, 159; Kaser Das Römische Privatrecht II 275 vn 14; Honsell, Mayer-Maly en Selb Römisches Recht 139 vn 14; Gordon Transfer of property 67 ev, 
noodsaaklik vir die oordrag van eiendomsreg nie. ${ }^{101}$ Dit blyk duidelik uit 'n keiserlike verordening van Diocletianus (293nC) wat ook in die Codex Justinianus opgeneem is, ${ }^{102}$ en wat handel oor die geval waar dieselfde saak aan twee verskillende persone verkoop is. Die een was fisies in beheer van die saak, terwyl die ander slegs 'n vervreemdingsakte kon toon. Die persoon aan wie fisiese beheer verskaf is, is as eienaar beskou, en nie die persoon aan wie die akte oorhandig is nie. Dit bewys dat verskaffing van fisiese beheer deurslaggewend was. ${ }^{103}$

Daar kan dus 'n sterk saak daarvoor uitgemaak word dat die verkryging van fisiese beheer steeds die grondbeginsel was. ${ }^{104}$ Indien die koopprys betaal is, en die vormvoorskrifte is nagekom, maar fisiese beheer is nog nie verskaf nie, het eiendomsreg waarskynlik nie oorgegaan nie. Hierdie standpunt word gesteun deur die feit dat die koper, in 'n stelsel waar fisiese beheer 'n deurslaggewende rol gespeel het, waarskynlik nie bereid sou gewees het om die koopprys te betaal nie, tensy hy fisies in beheer gestel word. Daar kan dus hoogstens gesê word dat die vormvereistes en prysbetalingsreël verskaffing van fisiese beheer op die agtergrond geskuif het, maar nie dat dit in die plek daarvan gekom het nie.

Die enigste geval waar verskaffing van fisiese beheer nie 'n vereiste vir die oordrag van eiendomsreg was nie, is waar 'n saak geskenk is, en die skenker vruggebruik op die saak vir homself voorbehou het (retentio ususfructus). Die gebruik ontstaan later om die voorbehoud bloot vir die skyn by die skriftelike kontrak in te voeg, slegs ter wille daarvan om die vereiste dat fisiese beheer verskaf word (wat in geval van skenkings wetlik voorgeskryf is) te omseil. Die begunstigde word sodoende eienaar, sonder dat hy fisies in beheer van die saak gestel word. ${ }^{105}$

\section{Oordrag van eiendomsreg deur wilsooreenstemming}

Uit bogenoemde bespreking blyk dit dat die oordrag van eiendomsreg deur traditio wat op 'n koop of skenking gegrond is, die volgende handelinge omvat het: die ooreenkoms tussen vervreemder en

82-95; Dondorp en Schrage Levering 23-25. Brunner Rechtsgeschichte 90, 112-116 se teenstrydige standpunt in hierdie verband is nie aanvaarbaar nie, en berus op 'n foutiewe interpretasie van Codex Justinianus 8.53(54).1.

101 Dws dat eiendomsreg oorgegaan het selfs al is daar nie 'n akte opgestel en oorhandig nie. Aan die ander kant het eiendomsreg nie oorgegaan bloot op grond van die feit dat 'n akte opgestel en oorhandig is nie. Die akte was dus nie deurslaggewend nie.

102 Codex Justinianus 3.32.15; Dondorp en Schrage Levering 24.

103 Dondorp en Schrage Levering 23-24.

104 Sien ook Honsell, Mayer-Maly en Selb Römisches Recht 138-139; Dondorp en Schrage Levering 23-24.

105 Sien Levy West-Roman Law 144; Kaser Privaatrecht 121. 
verkryger wat gewoonlik op skrif gestel en in openbare registers geregistreer is, ${ }^{106}$ betaling van die koopprys deur die koper, en verskaffing van fisiese beheer wat op die grondstuk voor getuies plaasvind. ${ }^{107}$ Indien 'n ander saak as grond oorgedra is, is fisiese beheer op een van die erkende wyses verskaf. ${ }^{108}$ Eiendomsreg het oorgegaan deur sluiting van die koopkontrak wat tegelykertyd ook saaklike oordragshandeling was. ${ }^{109}$ Dit spreek vanself dat die vraag of traditio abstrak dan wel kousaal was, nie ter sprake gekom het nie aangesien oordrag nie op 'n voorafgaande causa gegrond was nie - die sluiting van die koopkontrak was meteens oordragshandeling.

Dit is algemeen bekend dat eiendomsreg in die Suid-Afrikaanse reg deur lewering en die saaklike ooreenkoms oorgedra word. Die saaklike ooreenkoms bestaan uit die bedoeling (wilsooreenstemming) om eiendomsreg oor te dra en te ontvang. Kenmerkend van hierdie ooreenkoms is dat dit van die verbintenisskeppende ooreenkoms geabstraheer is. Alhoewel daar nie sprake van 'n afsonderlike saaklike ooreenkoms in die vulgêre reg was nie, ontstaan die vraag watter rol die wilsooreenstemming betreffende die oordrag en ontvangs van eiendomsreg (die bedoeling om eiendomsreg oor te dra en te ontvang) gespeel het.

Die feit dat eiendomsreg in die vulgêre reg regstreeks oorgegaan het deur sluiting van die koop of skenking, en die feit dat die verskaffing van fisieser beheer op die agtergrond geraak het, regverdig die standpunt dat die bedoeling om eiendomsreg oor te dra en te verkry, al hoe meer op die voorgrond getree het. ${ }^{110}$ Dit wil egter nog nie sê dat eiendomsreg oorgegaan het uit hoofde van 'n afsonderlike bedoeling wat van die koop of skenking geabstraheer is nie. Die bedoeling om eiendomsreg oor te dra verwys slegs na wilsooreenstemming tydens sluiting van die kontrak, en nie na 'n saaklike ooreenkoms nie. Dit was met ander woorde die verbintenisregtelike kontrak wat daarvoor verantwoordelik was dat eiendomsreg oorgegaan het - eiendomsreg het direk deur die koop of skenking, wat tegelykertyd ook oordrag van fisiese beheer bewerkstellig het, oorgegaan. ${ }^{111}$

\section{Gevolgtrekking}

Anders as wat in die Suid-Afrikaaanse reg die geval is, was een enkele verhouding, naamlik diè tussen die verbintenisskeppende ooreenkoms en verskaffing van fisiese beheer in die vulgêre reg

106 Igv skenking was skrif en registrasie deur wetgewing vereis, igv koop het die partye vrywillig van dokumente gebruik gemaak vir bewysdoeleindes, en die praktyk was dat so 'n dokument geregistreer word.

107 Levy West-Roman Law 129, 132.

108 Kaser Das Römische Privatrecht II 280. Sien ook Levy West-Roman Law 135.

109 Dit was een enkele handeling. Levy West-Roman Law 129, 140.

110 Dondorp en Schrage Levering 24; Honsell, Mayer-Maly en Selb Römisches Recht 138-139, 159-160. 
oorheersend. Daar was nie eens 'n definitiewe onderskeid tussen die verbintenisskeppende ooreenkoms en verskaffing van fisiese beheer nie. ${ }^{112}$ Totstandkoming van die koopkontrak was tegelykertyd ook saaklike oordragshandeling. ${ }^{113}$ Eiendomsreg het oorgegaan deur sluiting van die koopkontrak en verskaffing van fisiese beheer ${ }^{114}$ (wat een handeling was) mits die vormvoorskrifte, wat die doel gedien het om die invordering van belasting te vergemaklik, nagekom is.

Alhoewel dit praktyk was om skriftelike aktes van die koopkontrak op te stel en in munisipale registers aan te teken, was dit nie konstitutiewe vereistes vir die oordrag van grond nie. ${ }^{115}$ Hierdie vereistes het regsekerheid bevorder, en dit het tot gevolg gehad dat publisiteit aan die oordrag verleen word, alhoewel dit nie die bedoeling daarmee was nie. ${ }^{116}$

Alhoewel die bedoeling om eiendomsreg oor te dra en te ontvang 'n belangrike rol gespeel het, het eiendomsreg nog nie oorgegaan uit hoofde van 'n afsonderlike bedoeling wat van die koop geabstraheer is nie. ${ }^{117}$ Daar was dus in die vulgêre reg nog geen sprake van 'n afsonderlike en geabstraheerde saaklike ooreenkoms nie.

111 Levy West-Roman Law 127 (in vn 7 op 128 sê hy pertinent dat eiendomsreg nie deur blote wilsooreenstemming oorgegaan het nie); Molkenteller Dinglichen Vertrag 69.

112 Die onderskeid wat in die klassieke reg tussen die grondliggende ooreenkoms (causa) en die verskaffing van fisiese beheer (traditio) as die saaklike oordragshandeling getref is, het verdwyn.

113 Sluiting van die koopkontrak, betaling van die koopprys en oordrag van die koopsaak is gelyktydig uitgevoer.

114 Nieteenstaande die feit dat fisiese beheer op die agtergrond geraak het (eiendom sonder daadwerlike fisiese beheer was byvoorbeeld moontlik), was die verskaffing van fisiese beheer steeds 'n vereiste vir die oordrag van eiendomsreg.

115 Dit was wel 'n konstitutiewe vereiste in geval van skenkings.

116 Kaser Das Römische Privatrecht II 74, 275.

117 Eiendomsreg het oorgegaan deur sluiting van die koopkontrak wat ook oordragshandeling was. 


\section{Bibliografie}

Brunner Rechtsgeschichte

Brunner H Zur Rechtsgeschichte der Römischen und Germanischen Urkunde (Weidmann Berlyn 1880)

Corpus Iuris Civilis

Corpus Iuris Civilis reds JE Spruit R Feenstra en KEM Bongenaar (Walburg Zutphen 1993)

\section{Corpus Iuris Civilis}

Corpus Iuris Civilis reds P Krüger en T Mommsen (Apud Weidnaanes 18861888)

Delport Eiendomsoordragshandelinge

Delport JT Lewering en Registrasie as Eiendomsoordragshandelinge in die Suid-Afrikaanse Reg (LL D-proefskrif UPE 1976)

Dondorp en Schrage Levering

Dondorp JH en Schrage EJH Levering Krachtens Geldige Titel (VU Uitgeverij Amsterdam 1991)

Feenstra Romeinsrechtelijke Grondslagen

Feenstra R Romeinsrechtelijke Grondslagen van het Nederlands Privaatrecht 5e uitg (Brill Leiden 1990)

Gordon Transfer of property

Gordon WM Studies in the Transfer of Property by Traditio (University of Aberdeen Aberdeen 1970)

Honsell, Mayer-Maly en Selb Römisches Recht Honsell H, Mayer-Maly T en Selb W Römisches Recht 4e uitg (Springer-Verlag Berlyn 1987)

Kaser Das Römische Privatrecht 
Kaser M Das Römische Privatrecht I (Beck München 1971)

Kaser Das Römische Privatrecht

Kaser M Das Römische Privatrecht II (Beck München 1975)

Kaser Privaatrecht

Kaser M Romeins Privaatrecht (deur FBJ Wubbe uit die oorspronklike Nederlands vertaal) 2e uitg (NV Uitgeversmaatschappij Zwolle 1971)

Kop 'Vulgaire' Romeinse Recht

Kop PC Beschouwingen over het zgn 'Vulgaire' Romeinse Recht (Universitaire Pers Leiden 1980)

Levy West-Roman Vulgar Law

Levy E West-Roman Vulgar Law: the Law of Property (American Philosophical Society Philadelphia 1951)

Lokin Vermogensrechtelijke Leerstukken

Lokin JHA Prota, Vermogensrechtelijke Leerstukken aan de hand van Romeinsrechtelijke Teksten uitgelegd (Rijksuniversiteit Groningen 1991)

Molkenteller Dingliche Vertrag

Molkenteller DH Die These vom Dingliche Vertrag (Peter Lang Frankfurt 1991)

Van der Walt Houerskap

Van der Walt AJ Die Ontwikkeling van Houerskap (LL D-proefskrif PU vir CHO 1985)

Van Oven Romeinsch Privaatrecht

Van Oven JC Leerboek van Romeinsch Privaatrecht 3e uitg (Brill Leiden 1948)

Van Zyl Romeinse Privaatreg

Van Zyl DH Geskiedenis en Beginsels van die Romeinse Privaatreg (Butterworths Durban 1977)

Voß Kaisergesetzen der Spätantike

Voß WE Recht und Rhetorik in den Kaisergesetzen der Spätantike: eine Untersuchung zum Nachklassischen Kauf- und Übereignungsrecht (Löwenklau Frankfurt am Main 1982) 


\section{Register van hofsake}

Air-Kell h/a Merkel Motors v Bodenstein 19803 SA 917 (A) 